\title{
Can There Be An East Asian Donor Model? A Comparative Study of South Korea, China and Japan
}

\author{
Sojin Lim (KOICA ODA Research Team)
}

\section{Contents}

I . Introduction

II. Research Methods

III. Comparison amongst South Korea, China and Japan

1. South Korea

2. China

3. Japan

IV. Concluding Remarks

\section{I . Introduction}

Development assistance by Japan, China and South Korea, time for cooperation and competition has come (Kitano, 2012).

According to Stallings (2013), it seems that East Asian donors show similarities in the patterns of official development aid (ODA) compared to so-called Western donors, in terms of geographical allocation, sectoral allocation, grants and loans profile and 
public-private links. First, while East Asian donors tend to provide their aid mostly to Asia region, Western donors, especially the Organisation for Economic Co-operation and Development (OECD) Development Assistance Committee (DAC) donors, show a tendency to focus on lower income countries. Second, East Asian donors emphasise economic infrastructure, whereas Western donors allocate aid at the social sector. Third, it seems that East Asian donors provide more loans than grants, which is opposite tendency to Western providers. Furthermore, East Asian donor countries consider the public-private relation as a 'large package' within the public-private partnership framework, whilst Western aid providers tend to show a division of labour approach between public and private sectors.

At the country level, in the case of Cambodia, South Korea (hereinafter, Korea), China and Japan have been the top three donors (Ky et al., 2012). According to Ky et al. (2012), all of the three countries have provided both grants and loans to Cambodia, while Japan has been recorded as the highest grant provider and China focuses on loans rather than grants. In the case of Korea, it tends to increase loans against grants in Cambodia since its commencement of DAC membership (Ky et al., 2012). In terms of objectives of ODA, these differ among the countries. While it is said that Korea's interest in providing aid to Cambodia has been unclear, Japan shows strong interests in the recipient's national security, economic development and humanitarian reasons (Ky et al., 2012). On the other hand, China shows higher interests in national resources (Stallings, 2013).

From the existing literature, the main features that determine the Asian donor model amongst Korea, China and Japan can be found in their geographical aid allocation with a focus on the Asia region, although it is the second priority region in China's case. At the same time, the determinants show that the Asian donor model tends to emphasise on both infrastructure and loans with a less organised approach compared to the traditional donors. However, few studies have analysed and compared the aid management systems of East Asian donors and the motivations behind aid.

With this in mind, this study aims to examine determinants in order to look at whether 
there can be an Asian donor model, by analysing: 1) the aid modalities and management systems, 2) aid allocation; and 3) Korea, China and Japan's motivations for aid, despite their fundamental differences. Japan is a traditional OECD DAC donor, Korea is a new DAC member, and China is both non-DAC donor and recipient.

\section{Research Methods}

While this paper mainly uses the document analysis method, the observation method is also used through participation in various seminars and workshops related to ODA issues in Korea, Japan and China. Also observation from the field work in developing countries is also employed. Moreover, the interview method is also used with government officials. For document analysis, the OECD DAC peer reviews have been the main source of the analysis, along with aid white papers. For the case of Korea, the author's own experiences at the Korea International Cooperation Agency (KOICA) are reflected as well.

\section{Comparison amongst South Korea, China and Japan}

\section{South Korea}

\subsection{Aid Modality and Management System}

Korea's ODA is divided into two pillars of grants and loans, and these are again divided into other two categories of multilateral and bilateral assistance. For bilateral aid management, the Ministry of Foreign Affairs (MOFA) is the main body for grant-type aid, while the Ministry of Strategy and Finance (MOSF) deals with the loan-type aid in Korea. In terms of multilateral aid management, MOFA mainly deals with UN system 
whereas the MOSF provides loans to multilateral development banks (MDBs), such as the World Bank and Asian Development Bank (ADB). However, for both grants and loans, the MOSF solely takes the final approval role of the whole system (OECD, 2012).

While both MOFA and MOSF are responsible for aid policies, KOICA and Exim Bank working as main bodies for aid execution in Korea. As KOICA is under the MOFA structure, it exclusively provides grant-type aid. In comparison, Exim Bank, being under the MOSF structure, provides loans in the form of Economic Development and Cooperation Fund (EDCF) to developing countries. However, in Korea, it is not only KOICA and Exim Bank which implement aid provisions. Other institutions, such as the Korea Development Institute (KDI), are also working on aid practices. KDI has provided the Knowledge Sharing Programme (KSP), which is composed of grant-type aid for economic development consultation in developing countries, but managed by MOSF, not by MOFA. Here, it seems that MOSF does not provide only loans, but also grants to some extent. Additionally, KOICA has provided the Development Experience Exchange Partnership (DEEP) as a knowledge sharing programme.

In the past, the bipolarised aid management system in Korea was under review by the OECD DAC Special Review team, and in 2006 the government of Korea decided to establish the Committee for International Development Cooperation (CIDC) chaired by the Prime Minister in order to link the policy level process between MOFA and MOSF (OECD, 2008). As the CIDC was commenced, other line ministries and institutions which are involved in Korean aid operational process have participated in the policy discussion. According to the OECD DAC Peer Review results, over 30 governmental institutions have provided ODA to developing countries from Korea (OECD, 2012: 62). Figure 1 summarises Korea's aid management system. 
〈Figure 1〉 Korea Aid Management System

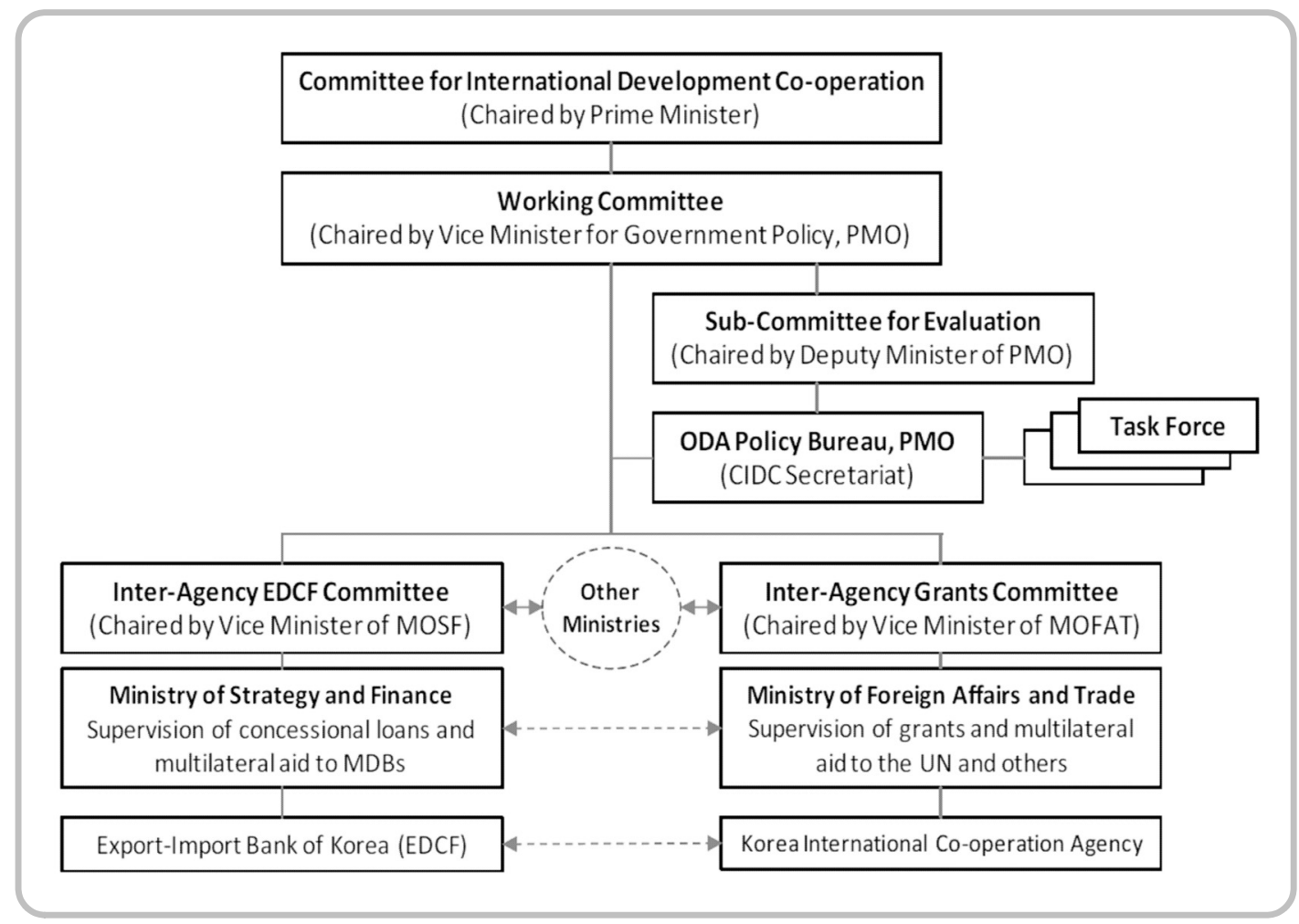

Source: Adopted from OECD, 2012: 63

\subsection{Aid Allocation}

Aid allocation by Korea to developing countries can be divided into two main channels of bilateral and multilateral. Ratio between bilateral and multilateral was recorded as 75:25 in 2011, compared to that of 83:17 in 2006. Currently, it is believed that Korea provides more proportion of aid through the multilateral channel, which records about 30 percent (OECD, 2012: 49). Between grants and loans, currently the ratio is 60:40, relatively (OECD, 2012: 53). As of 2011, Korea's ODA reached USD 1,325 million, which was equivalent to 0.12 percent of its GNI (OECD, 2012: 46). As the government announced, Korea is planning to increase its ODA/GNI ratio up to 0.25 percent by 2015 . In terms of untied aid, it has projected an increase of untied aid rate from 38.7 percent in 2008 to 75 percent by 2015 (OECD, 2008 \& 2012). Korea's ODA trend is shown in Figure 2 . 
〈Figure 2〉 Korea's ODA, 2006-2015 (disbursement, current prices USD millions)

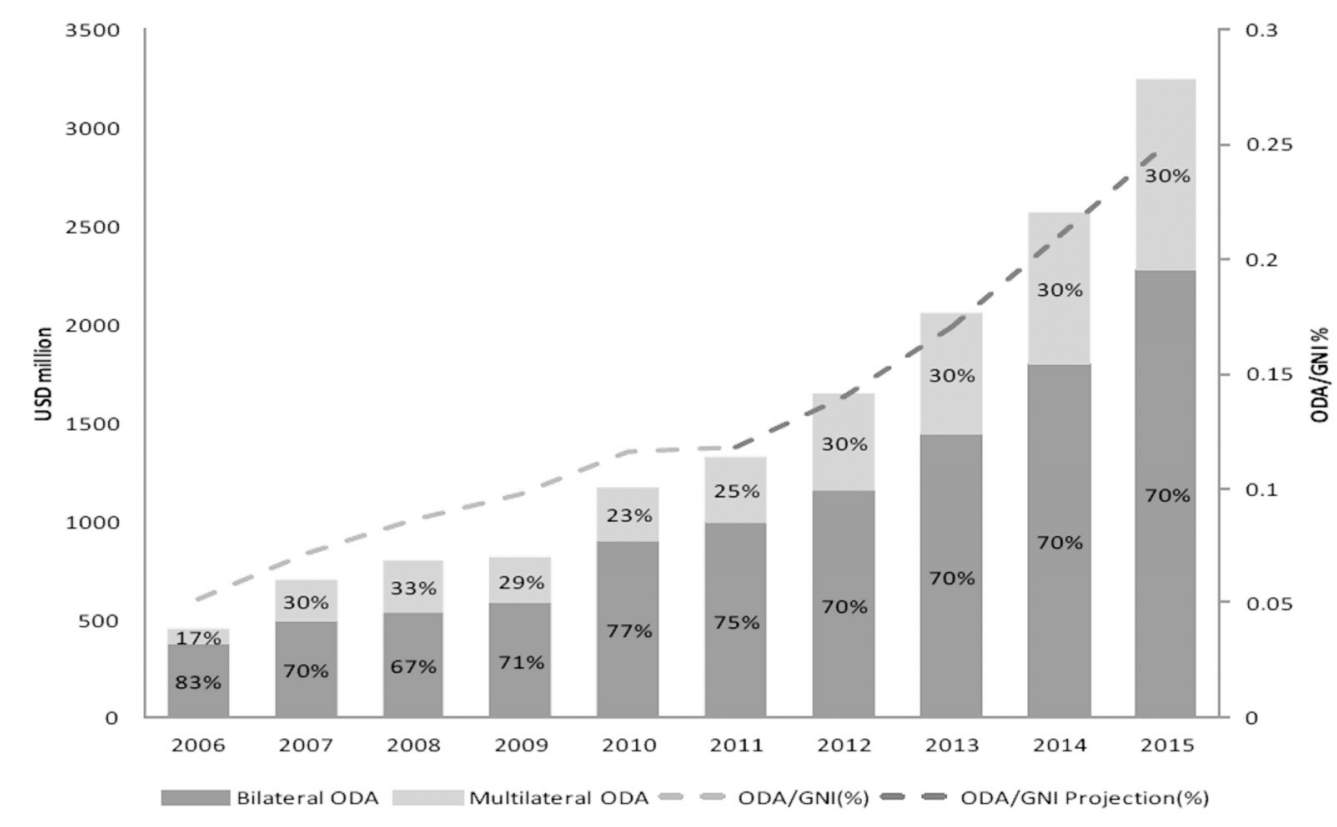

Source: Adopted from OECD, 2012: 46

In 2012, Korea provided its aid to 26 priority countries. Korea's top ten recipient countries are Vietnam, Afghanistan, Mongolia, Bangladesh, Sri Lanka, Indonesia, Cambodia, Philippines, Laos and Angola, which are mostly Asian developing countries. The Africa region has recorded Korea's second largest ODA recipient region following the Asia region; however, the absolute amount of Korean ODA is significantly higher in the Asia region than in the Africa region. In the future, the government of Korea is expected to increase its ODA proportion more to the poorest countries, such as least developed countries (LDCs), low-income countries (LICs) and heavily indebted poor countries (HIPCs). At last, in terms of sector allocation of ODA, Korea tends to focus on economic infrastructure, and this is mainly due to its loan distribution policy by MOSF and EDCF. The second largest sector of Korea's ODA distribution is 'education, health and population', and the third is other social infrastructure, as indicated by the OECD DAC Peer Review analysis (OECD, 2012). 


\subsection{Motivation of Aid}

According to the OECD DAC Peer Review, Korea's ODA is a part of its foreign policy. In this sense, ODA is at the core of the second key diplomatic task of the MOFA: diplomacy that contributes to global co-prosperity (OECD, 2012: 26). In other words, it can be interpreted that Korea's motivation for ODA is due to its political interests. On the other hand, it is observed that MOSF has a different tendency in providing ODA to developing countries from the recent forums held in Korea. For example, it was said that Korea's ODA should be considered in promoting more engagement of the domestic private sector in developing countries as a way to enlarge market shares (Korea Exim Bank, 2013: 3; Ham, 2013: 61-64; OECD, 2012: 32). That is, Korea's ODA is provided also on the basis of commercial interests.

\section{China}

\subsection{Aid Modality and Management System}

In the case of China, it is necessary to discuss how the Chinese government defines ODA as it is still an aid recipient and donor country at the same time. Chinese government tends to prefer using the term 'assistance between two South-South partners for mutual benefits' based on good friendship than using 'aid from donor to recipient' (McCormick, 2008). However, as the Chinese aid system has been developed further, it has been observed that the government of China and Chinese scholars also use the term 'foreign aid' (for instance, see Liu, 2013). As a matter of fact, the first Chinese White Paper on aid was named as 'China's Foreign Aid' (see IOSC, 2011).

Like other donor countries, Chinese aid is also composed of monetary and non-monetary forms, such as debt relief, complete projects, materials and goods, technical cooperation, human resource development cooperation, medical teams, humanitarian aid, and volunteer programmes (McCormick, 2008; Li, 2013; Liu, 2013). These forms can be categorized into grant aid, interest-free loans (interest-low loans or 
zero-interest loans) and concessional loans (Reisen and Ndoye, 2008; Li, 2013; Liu, 2013). However, unlike other donors, China barely provides its aid through a multilateral channel, but mostly through a bilateral channel (IOSC, 2011). Instead of financial contribution, the Chinese government has cooperative working process with multilateral organisations, such as the United Nations (UN) system and OECD. For example, the International Poverty Reduction Centre in China (IPRCC) was established both by the Chinese government and United Nations Development Programme (UNDP) in 2005. In this Centre, not only the Chinese government and UNDP, but also the World Bank, ADB and bilateral agencies like the United Kingdom (UK) Department for International Development (DFID) have worked as members of the Board of Trustees (IPRCC, 2008). With the OECD, the government of China has been heavily involved in the DAC Network on Poverty Reduction (POVNET), and China and the OECD have held workshop series on China's experience of poverty reduction.

While the Chinese aid modality composition is similar to other traditional donors, its aid management system is somewhat different. For example, China does not have a dedicated aid agency yet. Instead, the Ministry of Commerce (MOFCOM) has worked as the administrative body to oversee foreign aid in China, authorised by the State Council. In the field, Chinese embassies or consulates are responsible for the local aid management. However, when providing aid, the Ministry of Foreign Affairs, Ministry of Finance and the Export-Import Bank of China work together with the MOFCOM. At the same time, departments of the State Council also engage in the aid programme management process since it is necessary to provide higher level of professional expertise. In 2008, the government of China established an aid inter-agency liaison mechanism amongst the MOFCOM, Ministry of Foreign Affairs and Ministry of Finance. This mechanism was once upgraded into an inter-agency coordination mechanism in 2011 (IOSC, 2011). China's aid management system is illustrated in Figure 3. In addition, Figure 4 demonstrates an example of how Chinese aid modality with various organisational partners has been organised at the operational level in countries. 
〈Figure 3〉 Chinese Aid Management System

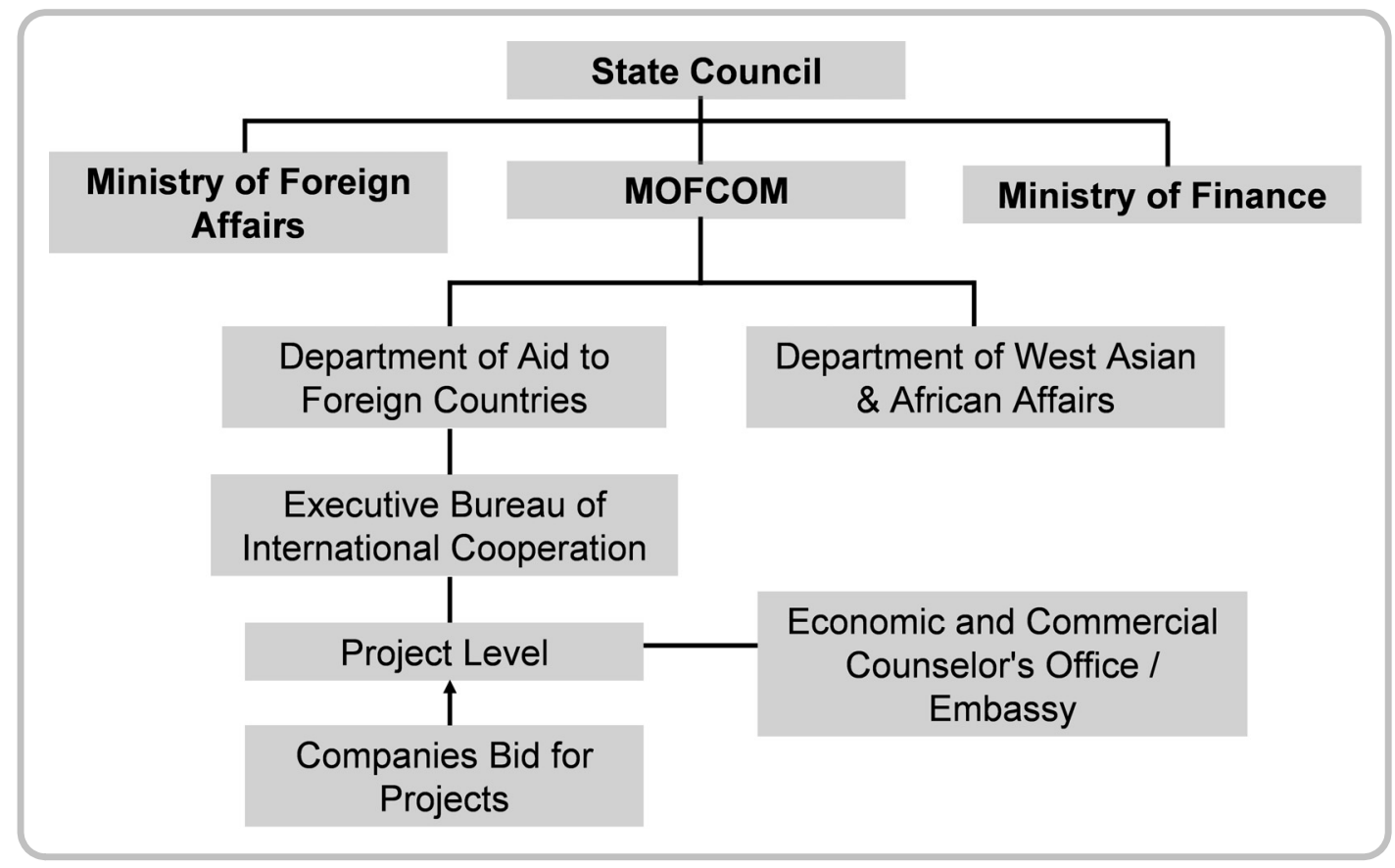

Source: Adopted from Davies, 2007: 46

〈Figure 4〉 Chinese Aid Mechanism in Africa

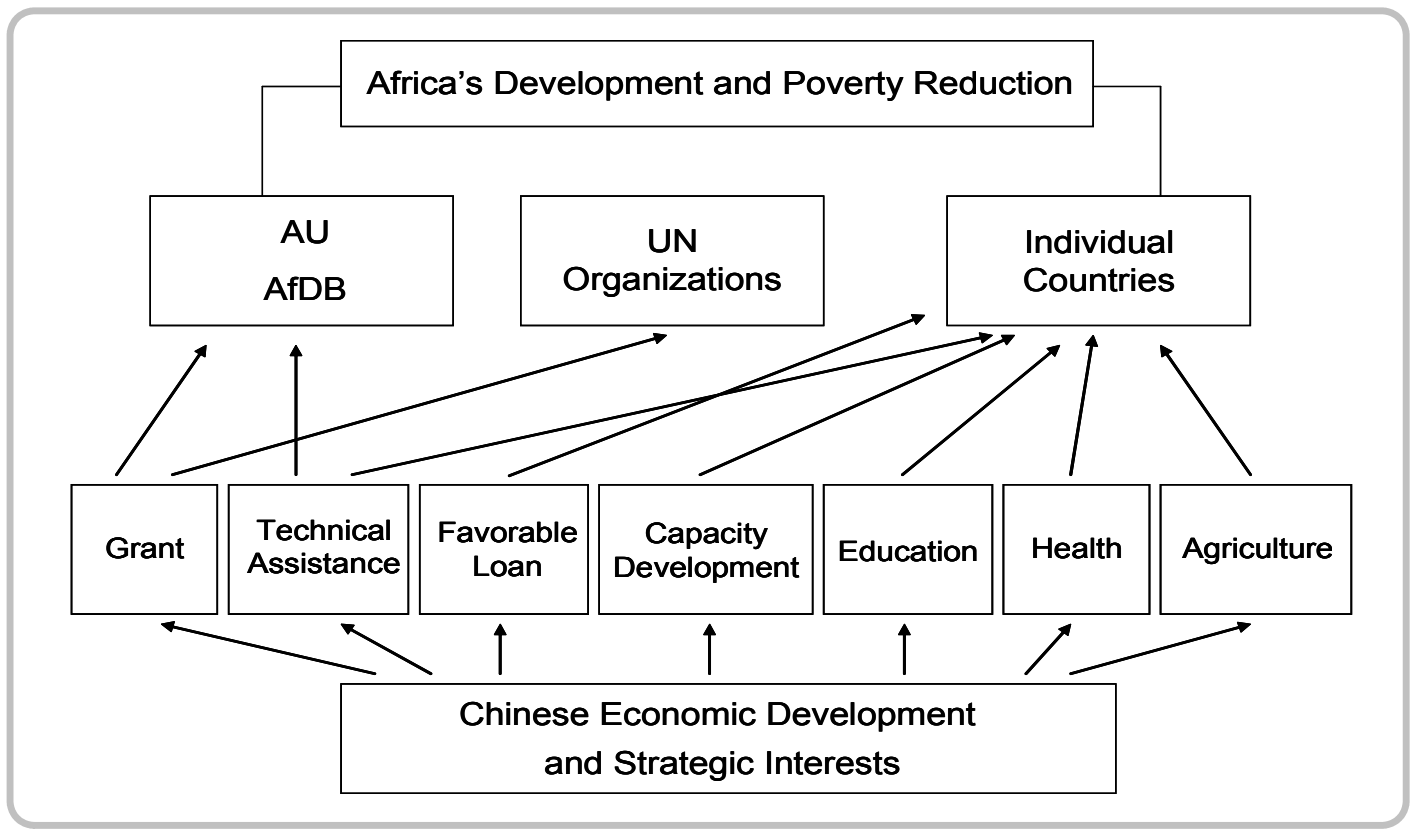

Source: Adopted from Li, 2008 


\subsection{Aid Allocation}

As of 2009, financial resources provided by the Chinese government in terms of foreign aid were USD 39 billion. Out of this, grants recorded about USD 16 billion, interest-free loans was USD 12 billion and concessional loans was USD 11 billion (Liu, 2013). In other words, 38 percent of Chinese aid was provided by the form of grants, 15 percent was by interest-free loans and other 47 percent was by concessional loans (Li, 2013).

While it is unclear how much aid has been distributed by each country, it is obvious that China has provided its aid to the Africa region at the highest rate, 46 percent. The second recipient group in terms of distribution rate can be found in the Asia region, with 33 percent of Chinese aid. In comparison, Latin America region recorded 12 percent of Chinese total aid amount ( $\mathrm{Li}, 2013$; Liu, 2013). By income group, China has distributed aid to the LDCs by 40 percent, to LICs by 23 percent, to lower middle income countries (LMICs) by 20 percent, to upper middle income countries (UMICs) by 11 percent and to others by 6 percent (Li, 2013; Liu, 2013). All of the statistics is based on the record of year 2009, which was published in 2011 by the government of China.

By sector allocation of aid, the government of China tends to emphasise economic infrastructure: 61 percent of Chinese concessional loans was allocated in economic infrastructure sector in 2009. Compared to the economic infrastructure sector, only 16 percent of Chinese concessional loans were provided to the industry sector, while 9 percent were allocated to energy and resources sector. The rest of Chinese concessional loans were provided to agriculture, public facilities, and others by 4 percent, 3 percent and 7 percent each (Liu, 2013). Unfortunately, there is no clear recent data for Chinese aid allocation grants and interest-free loans by sector.

\subsection{Motivation of Aid}

It has been controversial whether China provides aid on the basis of commercial interests, focusing on natural resources in other South partner countries. While 
academics criticise Chinese aid for being heavily focused on the Africa region due to its strategic interests in energy, such as oil and raw materials (for example, Lancaster, 2007; Reisen and Ndoye, 2008), Chinese government officials claim the analysis has been exaggerated as China has enhanced relations with countries with little natural resources, such as the Democratic Republic of the Congo (DRC), Mali, Tanzania and Zambia. For example, China's aid allocation amount to Tanzania is higher compared to that of Sudan and Nigeria, according to Chinese officials (Interviewed in 2008). At the same time, it has been emphasized that China provides both grants and loans with 'interest-free' for mutual benefits between China and other South partners (Xue, 2008). Apart from oil interests, however, it seems that China has strong interests in overall natural resources. China has made a USD 2.6 billion mining agreement of iron ore in Liberia, provided USD 95 million loan for uranium mining project in Niger, and established a gold consortium in Sudan (Butty, 2009; Lewis, 2009; Sudan Tribune, 2009). The contracts between Chinese private companies and other partner governments were made by negotiations proceeded by China Union as the company bid for projects.

In the mean time, some scholars argue that China's aid motivation not only stems from oil interests but also from political and economic interests as a hegemonic power game in the international society (for instance, see McCormick, 2008). As a matter of fact, in December 2006 during the event of 'China's Africa Strategy: A New Approach to Development and Diplomacy?', it was said that Chinese interests in aid can be analysed in two pillars: 'its potential role in the world and international power'; and 'its potential cooperation with the US in Africa based on the oil share in the continent' (Carnegie Endowment for International Peace, 2007). At the same time, another motivation that should be addressed can be found in China's immigration policy. During field research in Tanzania in 2010, it was observed that Chinese labour tended to stay in Tanzania even after the termination of projects, especially construction projects. According to Mohan and Power (2008), political issues in recipient countries by Chinese immigration, particularly into African markets, have occurred. In fact, it easily observed that Tanzanian government officials have begun to be concerned with increasing Chinese occupation in the domestic markets. 


\section{Japan}

\subsection{Aid Modality and Management System}

Based on the recommendations made by the previous OECD DAC Peer Review in 2003, Japan conducted a major organisational reform and the 'old' Japan International Cooperation Agency (JICA) and Japan Bank for International Cooperation (JBIC) was merged into the 'new JICA' in 2008, under the Ministry of Foreign Affairs (MoFA). JBIC had formerly dealt with loans and some part of grants from MoFA in the past. The main reason of the OECD DAC recommendation for the merger was due to administrative costs over time and efficiency (OECD, 2010). Differences before and after the aid management system merge in Japan are shown in Figure 5. As shown, the new JICA now provides grants, loans and technical cooperation.

\section{〈Figure 5〉 Changes from old JICA to new JICA}

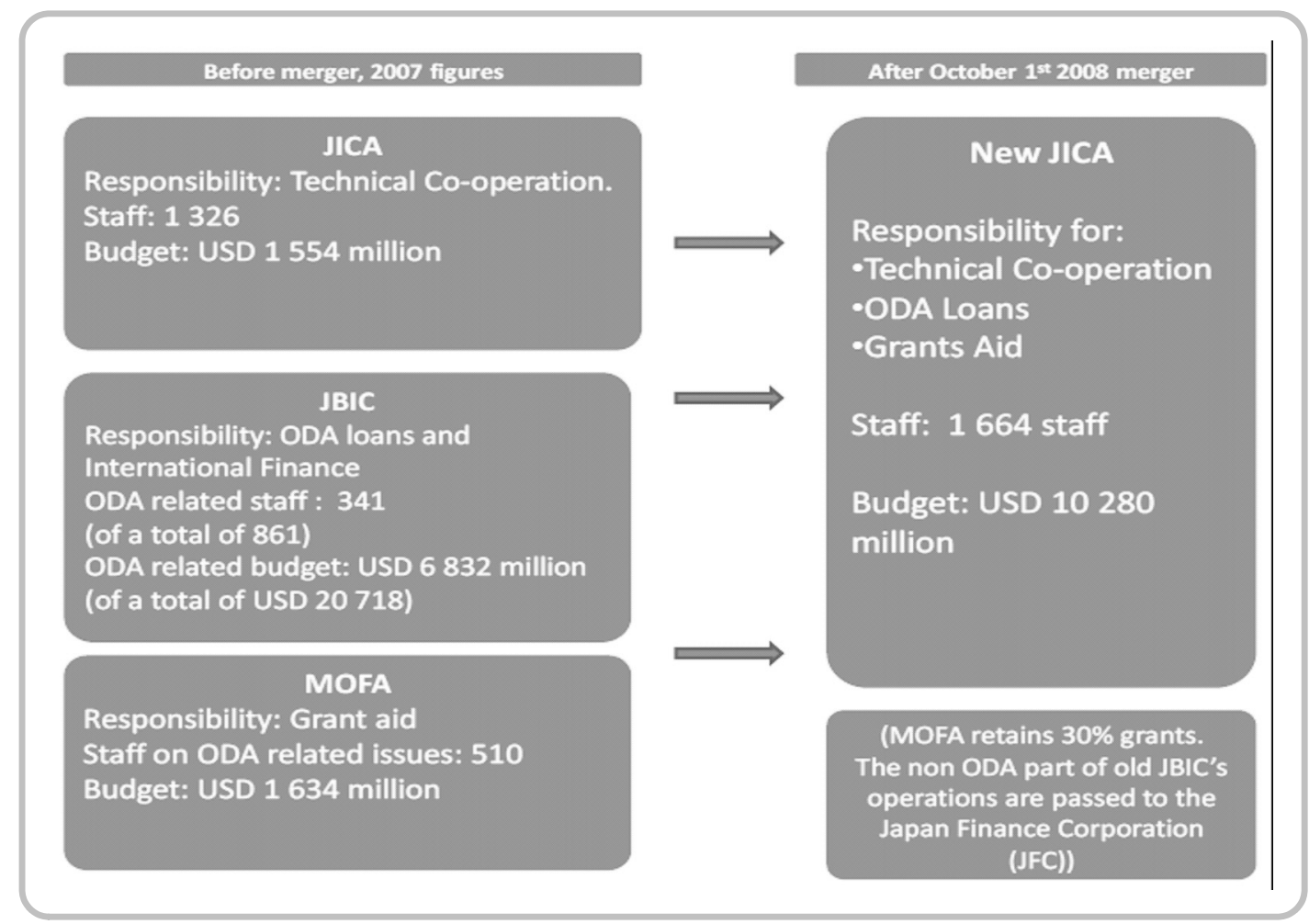

Source: Adopted from OECD, 2010: 54 
Currently in Japan, over 13 ministries and agencies are involved in the ODA system on the basis of policy coordination mechanism with three main building blocks. Among them, MoFA plays a central coordinating role for Japanese ODA with the new JICA. At the same time, the Ministry of Finance (MoF) plays a leading role in working with the World Bank, International Monetary Fund (IMF) and other regional development banks. MoF, along with the Ministry of Economy, Trade and Industry (METI), approve JICA loan budgets. At the policy level, the Overseas Economic Cooperation Council (OECC) supports the coordination role of MoFA, according to the very recent OECD DAC Peer Review in 2010 (OECD, 2010).

\subsection{Aid Allocation}

According to Japan's ODA White Paper 2012, about 89 percent of Japanese ODA amount consists of grants, while the rest 11 percent is composed of loans. Among grants, about 19 percent were distributed through a multilateral channel, whereas 81 percent of Japanese grants were allocated to developing countries. In terms of Japan's grants to multilateral institutions, about 70 percent of the 19 percent of total grant amount has been supported to UN organisations, whilst 30 percent out of the 19 percent of total grants are provided to developing countries through MDBs (MoFA, 2012: 178). Japanese aid allocation by region can be summarised as in Figure 6. 
〈Figure 6〉 Regional Allocation of Japanese ODA

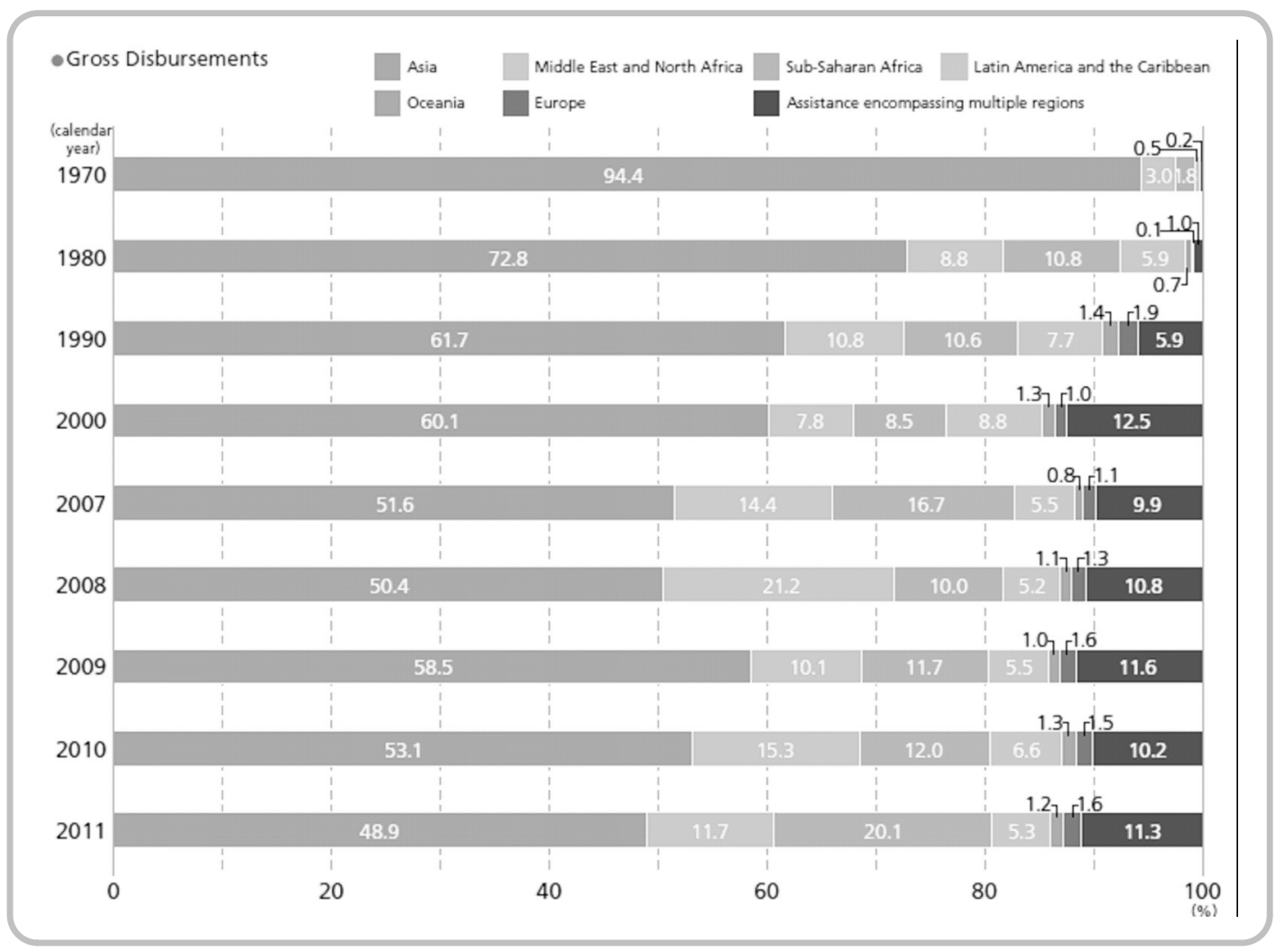

Source: MoFA, 2012: 50

As shown, although its ratio has decreased, the Asia region is still the major recipient of Japanese aid, while the Africa region is its second priority. By country, Iraq has received the largest amount of Japanese aid. The top ten recipient countries of Japanese ODA are Iraq, China, Indonesia, India, Vietnam, Philippines, Bangladesh, Tanzania, Turkey and Sri Lanka. By income group, Japan provided 37 percent of its aid to LDCs, 18 percent to LICs, 11 percent to LMICs, 10 percent to UMICs and 23 percent to unclassifiable countries. Here, the unclassifiable countries include aid distributed across multiple recipient countries (MoFA, 2012: 191).

In terms of sectoral distribution, Japan tends to emphasise economic infrastructure, followed by debt relief. Not as much emphasis is given to the economic infrastructure and debt relief sectors, but still to some extent, Japan has provided its aid to other social infrastructure and production. The education, health and population sector does 
not seem to be a priority in Japanese aid allocation (OECD, 2010).

\subsection{Motivation of Aid}

It is widely known that Japanese motivation for aid is based on its commercial interests of 'expanding exports and ensuring access to needed raw materials imports' (for example, see Browne, 1990; Lancaster, 2007: 110; Riddell, 2007). However, Japanese ODA is also influenced by the government's foreign policy. Japanese diplomatic goals have been reflected in aid provision, especially by human security. According to the recent aid white paper, Japanese government states that in philosophy, the objective of ODA is defined as to contribute to the peace and development of the international community and thereby to help ensure Japan's own security and prosperity' (MoFA, 2012: 55).

\section{Concluding Remarks}

This study has analysed the aid modality and management systems, aid allocation, and motivation of aid in Korea, China and Japan as Asian donor countries. First of all, the research has found that all of the three donors have both grants and loans profiles of aid, even though their portfolios differ. However, while both Korea and Japan have distributed their aid through both bilateral and multilateral channels, China has not contributed to the multilateral channel yet. Likewise, both Korea and Japan have dedicated aid operational agencies, such as KOICA and JICA, while China has yet to establish such an aid agency. However, more than three ministries are involved in aid mechanisms, at both the policy level and operational level of all three donors. Second, while Korea and Japan provide the largest amount of aid to the Asia region, China provides the largest amount of aid to the Africa region. In turn, the second priority region for aid allocation in both Korea and Japan is Africa, whilst Asia region has been the second priority region for China. However, the highest ratio of aid allocation by sector has been found to be economic infrastructure in all of these three donors. 
Finally, while both Korea and Japan have shown diplomatic and commercial interests in their aid policies, China shows stronger interests in natural resources. In the case of China, it has a tendency to relate its aid policies with its international political and economic policies.

As shown, there does not seem to be a clear definition for an 'Asian donor model' as the discussed three major Asian donors share similarities but process differences as well. Further, it is noteworthy that there might not be one model for Asian donors, but various models when it comes to other donors in Asia, such as Thailand, as Sőderberg (2010) argues. In the light of this, this study implies the need for further examination with more cases at a wider range of determining features for a single model in order to find concrete common features for Asian donor countries. 


\section{References}

Browne, S. (1990). Foreign Aid in Practice. New York: New York University.

Butty, J. (2009). Liberia Sings USD 2.6 Billion Mining Agreement with Chinese Company, Voanews, 23 January

Carnegie Endowment for International Peace (2007). China's Africa Strategy: A New Approach to Development and Diplomacy?, 12 December

Davies, P. (2007). China and the End of Poverty in Africa - towards Mutual Benefit? Sundbyberg, Diakonia.

Ham, M. (함미자) (2013). Discussion Paper at the Parliamentary Forum (박병석 국회부의장 주최 '해외원조 2조원, 어떻게 써야하나?' 토론회 유상원조에 대한 학계대표 토론자료). 19 August 2013.

IOSC (Information Office of the State Council) (2011). China's Foreign Aid (White Paper). The People's Republic of China.

IPRCC (International Poverty Reduction Centre in China) (2008). About us. Published in 2008. Available at: http://www.iprcc.org.cn [Accessed: 18 October 2013]

Kitano, N. (2012). Development Assistance by Japan, China and South Korea. JICA Opinion. 2 July 2012.

Korea Exim Bank (한국수출입은행) (2013). Interpreting the OECD DAC Peer Review (OECD $\mathrm{DAC}$ 동료평가의 쟁점과 해석). ODCF Issue Paper Vol.2 No.1.

Ky, S., C-W Lee and P. Stauvermann (2012). "A Comparative Study on Characteristics of ODA of China-Japan-Korea to Cambodia”. Journal of East Asian Economic Integration. 15(4): $333-361$.

Lancaster, C. (2007). Foreign Aid: Diplomacy, Development, Domestic Politics. Chicago: The University of Chicago.

Lewis, D. (2009). China Extends Niger USD 95 Million Loan for Uranium Project, Reuters UK, 24 April

Li, X. (2008). China's Foreign Aid and Aid to Africa: Overview. Presentation to the DAC Network on Poverty Reduction (POVNET) Workshop on China's Experience of Poverty Reduction at Home and in Africa. 21 February 2008. 
(2013). China' Development Cooperation: Overview. Presentation at the Seminar on East and North-East Asian Development Cooperation in Post 2015 in Beijing. 20 June 2013.

Liu, Q. (2013). China's Approach to Foreign Aid: Moving towards a New Aid Dynamic. Presentation at the Seminar on East and North-East Asian Development Cooperation in Post 2015 in Beijing. 20 June 2013.

McCormick, D. (2008). “China \& India as Africa's New Donors: The Impact of Aid on Development.” Review of African Political Economy 115: 73-92

MoFA (Ministry of Foreign Affairs) (2012). Japan's International Cooperation. Japan's ODA White Paper 2012.

Mohan, G. and M. Power (2008). "New African Choices? The Politics of Chinese Engagement." Review of African Political Economy 115: 23-42

OECD (2008). DAC Special Review of South Korea. Paris: OECD.

(2010). DAC Peer Review: Japan. Paris: OECD.

(2012). DAC Peer Review: Korea. Paris: OECD.

Reisen, H. and S. Ndoye (2008). Prudent versus Imprudent Lending to Africa: From Debt Relief to Emerging Lenders. OECD Development Centre Working Paper No. 268. Paris, OECD.

Riddell, R. (2007). Does Foreign Aid Really Work? New York: Oxford University Press.

Sőderberg, M. (2010). Challenges or Complements for the West: Is There An 'Asian' Model of Aid Emerging? In J. S. Sőrensen (ed). Challenging the Aid Paradigm: Western Currents and Asian Alternative. Hampshire: Palgrave MacMillan. 107-137.

Stallings, B. (2013). Japan, Korea and China: Patterns of ODA in East Asia. Presentation at the Seminar on East and North-East Asian Development Cooperation in Post 2015 in Beijing on 20 June 2013.

Sudan Tribune (2009). Sudanese-Chinese Consortium Signs Deal to Explores Gold, 16 May

Xue, H. (2008). Characteristics and Effectiveness of Chinese Foreign Aid. Speech Outlines of the Workshop on Managing Aid Effectively: Lessons for China? 27-28 March 2008. Beijing, China. 